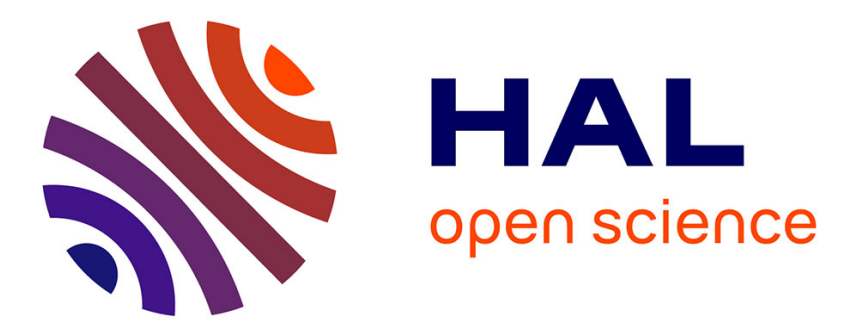

\title{
Chemoradiation in rectal squamous cell carcinoma: Bi-institutional case series
}

Gokoulakrichenane Loganadane, Stéphanie Servagi-Vernat, Antoine

Schernberg, Michel Schlienger, Emmanuel Touboul, Jean-François Bosset, Florence Huguet

\section{To cite this version:}

Gokoulakrichenane Loganadane, Stéphanie Servagi-Vernat, Antoine Schernberg, Michel Schlienger, Emmanuel Touboul, et al.. Chemoradiation in rectal squamous cell carcinoma: Bi-institutional case series. European Journal of Cancer, 2016, 58, pp.83-89. 10.1016/j.ejca.2016.02.005 . hal-01297489

\section{HAL Id: hal-01297489 \\ https://hal.sorbonne-universite.fr/hal-01297489}

Submitted on 4 Apr 2016

HAL is a multi-disciplinary open access archive for the deposit and dissemination of scientific research documents, whether they are published or not. The documents may come from teaching and research institutions in France or abroad, or from public or private research centers.
L'archive ouverte pluridisciplinaire HAL, est destinée au dépôt et à la diffusion de documents scientifiques de niveau recherche, publiés ou non, émanant des établissements d'enseignement et de recherche français ou étrangers, des laboratoires publics ou privés. 


\section{Original research article}

\section{Chemoradiation in rectal squamous cell carcinoma: bi-institutional case series.}

Gokoulakrichenane Loganadane ${ }^{\mathrm{a}}$, Stéphanie Servagi-Vernat ${ }^{\mathrm{b}}$, Antoine Schernberg ${ }^{\mathrm{a}}$, Michel Schlienger ${ }^{\mathrm{a}}$, Emmanuel Touboul $^{\mathrm{a}}$, Jean-François Bosset ${ }^{\mathrm{b}}$, Florence Huguet ${ }^{\mathrm{a}^{*}}$.

${ }^{a}$ Department of Radiation Oncology, Tenon Hospital, Hôpitaux Universitaires Est Parisien, Pierre and Marie Curie Paris 6 University, Paris, France;

${ }^{\mathrm{b}}$ Department of Radiation Oncology, Besançon University Hospital, Besançon, France.

Running title: Squamous cell carcinoma of the rectum.

*Corresponding author: Florence Huguet, MD, PhD, Department of Radiation Oncology, Hôpital Tenon, 4 rue de la Chine, 75020 Paris, France; Tel: +33156018322; Fax: +33156016400; Email: florence.huguet@aphp.fr

Keywords: squamous cell carcinoma; rectal cancer; chemoradiation; colostomy; survival; toxicity. 


\section{ABSTRACT}

Background and Purpose: Primary rectal squamous cell carcinoma (SCC) is an uncommon disease. Early reports stated that surgery is the most effective treatment. However, recent publications suggest conservative strategy with chemoradiation provides satisfactory results.

Patients and Methods: We have retrospectively studied the medical charts of 23 patients treated for a rectal SCC in two teaching hospitals in France between 1992 and 2013. Twenty-one patients received an exclusive chemoradiotherapy and two a pre-operative CRT followed by a planned surgery. Patients received pelvic irradiation with a dose ranging from 36 to 45 Gy followed by a boost of 15 to $23 \mathrm{~Gy}$. Twenty-two patients received a concurrent chemotherapy. Results: After CRT, the rate of clinical complete response was $83 \%$. With a median follow-up of 85 months, 5-year overall survival rate was $86 \%$. Five patients presented with a relapse. The 5-year disease-free survival rate was $81 \%$. The 5-year colostomy-free survival rate was $65 \%$. Three patients (13\%) presented with grade 3-4 late rectal toxicity.

Conclusions: Although retrospective, this is the largest cohort of patients treated with CRT for a rectal SCC. Exclusive CRT could result in high local control rate and prolonged survival in rectal SCC patients with a high rate of organ preservation. 


\section{Introduction}

Colorectal carcinoma is the third leading cause of death due to cancer worldwide. Squamous cell carcinoma (SCC) is an extremely rare subtype accounting for 0.1 to $0.25 \%$ of colorectal tumours. First described by Raiford in 1933 [1], one hundred cases have since been reported in the literature. The origin of the tumour remains unclear but several theories have emerged. Some authors suggest pluripotent stem cells with an epidermoid differentiation capacity. It has been hypothesized that mucosal aggression, secondary to bowel inflammatory disease, HPV infection, or ionizing radiations to cause squamous metaplasia underlying tumour development. Diagnosis requires rectoscopy or colonoscopy with biopsies of visible abnormalities. In 1979, Williams et al. [2] defined conditions to be fulfilled: (1) careful rectal endoscopy to exclude proximal extension of anal cancer, (2) primary SCC ruled out, (3) lack of a fistula tract lined by squamous cells, (4) absence of glandular differentiation.

The best therapeutic strategy for rectal SCC has to be defined. In non-metastatic patients, early reports supported radical surgery as the standard treatment [2,3]. However, based on the experience achieved in anal SCC patients, CRT has become the treatment of choice in most of cases. Radical surgery is limited to patients without response after CRT or at the time of relapse. This retrospective study aims to assess the outcome of patients with rectal SCC treated with CRT in two French university hospitals.

\section{Patients and Methods}

\subsection{Patient selection}

Between November 1992 and October 2013, 23 patients with rectal SCC were treated in the Departments of Radiation Oncology in Tenon Hospital, Paris ( $\mathrm{n}=13$ ) and Besançon University Hospital $(n=10)$. Patients with tumours involving the anal canal or the ano-rectal junction were excluded. We reviewed retrospectively medical charts of all patients for demographic data, 
tumour location and stage, and CRT characteristics. Disease staging was defined according to the 2002 American Joint Committee on Cancer (AJCC) anal cancer staging manual, sixth edition. The pre-treatment evaluation included physical examination, rectal endoscopy with tumour biopsy, transrectal EUS, abdominal ultrasound, and SCC antigen dosage. The study was approved by the Institutional Review Board of Tenon Hospital.

\subsection{Study treatment}

All patients started their treatment with CRT. All patients but two underwent a threedimensional conformal radiation therapy (3DCRT). Intensity-modulated radiation therapy (IMRT) by volumetric modulated arc therapy (VMAT) concerned two patients.

Patients in both centres were treated with radiation therapy plans quite similar to those of anal SCC [4].

A planning CT scan was required to define target volumes.

In Tenon hospital, the following volumes were based on the International Commission on Radiation Units and Measurements 50 Report [5]: the gross tumour volume (GTV) was determined on the planning CT scan; the clinical target volume (CTV) was defined as the GTV, anal canal, mesorectum, presacral nodes, bilateral internal, external and primitive iliac nodes, and inguinal nodes; the planning target volume 1 (PTV1) included the CTV plus a safety margin of $10 \mathrm{~mm}$ in all directions. In general, the upper beam limit of PTV1 was at the top edge of the sacral vertebral body 1 . After 45 Gy, the reduced PTV (PTV2) was limited to the GTV and the centimetric lymph nodes plus a margin of $10 \mathrm{~mm}$ in all directions. Treatment was performed with a linear accelerator of at least $6 \mathrm{MV}$ with an isocentric technique. Customized blocks or multileaf settings were used to minimize the radiation dose to the normal tissues and OARs. Total dose on PTV1 was 45 Gy in fractions of 1.8 Gy five times weekly. After a period of rest, the patients received in PTV2 a dose of 15 to $20 \mathrm{~Gy}$ in fractions of 1.8 Gy five times weekly. 
The Besançon University Hospital's treatment approach was based on EORTC recommendations [6]. For instance, the cranial border of beams was located on to the top of S2. The two sequences of irradiation of 36 Gy and 23.4 Gy were separated by two weeks of rest. Patients received concurrent chemotherapy with different regimens: cisplatin $\left(25 \mathrm{mg} / \mathrm{m}^{2}\right.$ on days $1-4$ and $29-32$ or $100 \mathrm{mg} / \mathrm{m}^{2}$ on days 1 and 29) and 5-fluorouracil (5FU) (800 to 1000 $\mathrm{mg} / \mathrm{m}^{2}$ on days $1-4$ and $\left.29-32\right)(\mathrm{n}=12)$; capecitabine $\left(825 \mathrm{mg} / \mathrm{m}^{2}\right.$ bi-daily every day of irradiation) and mitomycine $\mathrm{C}\left(10 \mathrm{mg} / \mathrm{m}^{2}\right.$ on days 1 and 50$)(\mathrm{n}=4) ; 5$-fluorouracil (5FU) (1000 $\mathrm{mg} / \mathrm{m}^{2}$ on days $1-4$ and $\left.29-32\right)$ and mitomycine $\mathrm{C}\left(10 \mathrm{mg} / \mathrm{m}^{2}\right.$ on days 1 and 50$)(\mathrm{n}=3)$; mitomycine $\mathrm{C}\left(10 \mathrm{mg} / \mathrm{m}^{2}\right.$ on days 1 and 50$)$ and cisplatin $\left(25 \mathrm{mg} / \mathrm{m}^{2} /\right.$ week $)(\mathrm{n}=1)$; weekly cisplatin $\left(40 \mathrm{mg} / \mathrm{m}^{2} /\right.$ week) $(\mathrm{n}=2)$. One patient did not receive concurrent chemotherapy because of very early stage (T1N0) and severe cardiac comorbidities.

\subsection{Follow-up}

During treatment, patients were evaluated weekly for toxicity by clinical examination. Complete blood count with differential and platelet counts, renal and liver function tests were performed before each cycle of chemotherapy.

The first assessment of the tumour response was performed by clinical examination and transrectal sonography two to six weeks after the first course of irradiation. In absence of response, the patient was referred to the surgeon to undergo abdominoperineal or low anterior resection.

The second assessment was done two to three months after the boost and included additionally SCC dosage, chest X-ray, and abdominal ultrasound. Follow-up clinical examination was performed every 3 months during the first year, then every 6 months during 4 years and annually thereafter.

\subsection{Statistical analysis}


The primary endpoints of the study were local control, disease-free survival (DFS), overall survival (OS), colostomy-free survival (CFS), sphincter function [7], and late complications according to the LENT-SOMA scoring system [8]. DFS was defined as the time interval from diagnosis (date of biopsy) to first disease progression or death from any cause if disease progression did not occur. Alive patients without progression were censored at the last followup. OS was defined as the time interval from diagnosis to death (from all causes) or last followup. Patients alive were censored at last follow-up. The CFS was defined as the number of patients alive without colostomy at the last follow-up. The primary efficacy endpoints were computed using the Kaplan-Meier method and compared using the log-rank test [9]. Statistical differences between survival curves were tested by the two-tailed log-rank test. In order to assess the precision of the obtained estimates, hazard ratios (HRs) and confidence intervals (CIs) 95\% were assessed from the Cox proportional hazards models. Chi-square test or Fisher's exact tests, when suitable, were used to compare the nonparametric and parametric qualitative data. Multiple regression analysis was used to study prognostic factors. Variables with a Pvalues $\leq 0.2$ in the univariable analysis were included in the multivariable analysis. Differences were assumed to be significant when $\mathrm{P}<0.05$. Analyses were performed using Statview® software version 5 (SAS Institute, Cary, NC, USA).

\section{Results}

\subsection{Study population}

Patient and tumour characteristics are summarized in Table 1. Overall, 23 patients with rectal SCC were treated in the Departments of Radiation Oncology in Tenon Hospital $(n=13)$ and Besançon University Hospital $(n=10)$. Most of the patients were women (87\%). The median age was 59.5 years (range, 42-88 years). Noteworthy, four women had a history of cervical intraepithelial neoplasia. HIV infection was not found. The presence of an HPV infection was 
searched in five tumour specimens by genotyping with polymerase chain reaction (INNOLiPA® HPV Genotyping Extra - Innogenetics). Among them, four were positive for HPV infection (80\%). Patients treated in Besançon had more advanced tumours (90\% of T3-T4 tumours versus $46 \%$ in Tenon).

\subsection{Treatment efficacy}

Treatment characteristics for all patients are presented in Table 2. In the evaluation conducted after the completion of the first course of radiation therapy, we observed a clinical complete response in five patients $(22 \%)$, a partial response in twelve patients $(52 \%)$, a response of less then $50 \%$ in four patients $(17 \%)$ and no response in two patients $(9 \%)$. The overall response rate was $74 \%$. Among the 23 patients, two patients with locally advanced disease (T3N1M0 and T4N1M0) with circumferential rectal involvement underwent a planned abdominoperineal resection (APR) with colostomy five weeks after the completion of the first course of radiation therapy. They did not receive an additional boost. Noteworthy, they had both a complete histologic response without residual tumour on the pathological specimen.

A clinical complete response was observed in 19 patients (83\%) after the completion of the treatment with the tumour boost showed. Two patients with residual disease underwent an abdominoperineal resection.

\subsection{Survival}

The median follow-up was 85 months (range, 12-161 months). Five patients (22\%) presented with a recurrence (Figure 1). Median time to recurrence was 13 months (range, 5-91 months). Two patients had an isolated local recurrence cured by a salvage surgery. Two patients presented with metastatic recurrence and one patient with a local progression and synchronous metastasis. The 5-year DFS rate was $81 \%$ (CI 95\%, 73-90\%) for the whole population (Figure 2). 
There were three deaths recorded. Two deaths occurred in patients with no evidence of tumour disease. The 5-year OS rate was 86\% (CI 95\%, 76-94\%) for the whole population (Figure 3). Overall, six patients (26\%) had a colostomy, among them four at the time of APR, one for tumour progression with rectal ulceration, and one for grade 4 rectal toxicity. The 5-year CSF rate was $65 \%$ (CI 95\%, 50-80\%).

\subsection{Tolerance}

Overall, during follow-up, eighteen patients (78\%) complained of at least one rectal late inconvenience. The most common symptoms were anal pain reported by ten patients (43\%), rectal bleeding reported by seven patients (30\%), and increase of stools reported by five patients $(22 \%)$. Three patients (13\%) presented with grade 3-4 late rectal toxicities: one case of grade 3 rectal ulcer and two cases of grade 4 rectovaginal fistula requiring a colostomy. No case of urologic or dermatologic severe late toxicity has been reported.

\section{Discussion}

Rectal SCC is an orphan disease with the four largest cases series reported by MSKCC [10], M.D. Anderson Cancer Center [11], Lyon [12], and Rome [13] including respectively 12, 14, 11, and 10 patients (Table 3). Given the rarity of this disease, data on pathogenesis, risk factors, prognosis, biological behaviour, and therapeutic management are lacking. In most cases, diagnosis occurred at advanced stage. Most of recent publications have used anal SCC TNM staging $[10,15]$ while some authors choose to classify their cases according to rectal adenocarcinoma TNM classification $[15,16]$.

In ancient surgical series, 5-year overall survival was $32 \%$ in rectal SCC, comparing poorly with $50 \%$ in rectal adenocarcinoma [17]. Surgery was supposed to offer the best chance of cure and has been widely used $[18,19]$. Surgical or endoscopic mucosal resection is appropriate in 
selected T1 tumours with mucosal invasion. For more advanced disease, abdominoperineal resection was the standard technique but carried a significant morbi-mortality.

This present study represents the largest series reported to our knowledge. We reviewed the outcomes of 23 patients treated in two French institutions. Most of our patients were successfully treated with exclusive chemoradiation. The 5 -year overall survival was $86 \%$. Local control was achieved in $83 \%$ of cases. These rates are consistent with those reported in the literature and are presented in Table 3 [10-14,16,20-22].

Several concurrent chemotherapy regimens were given to our patients but mostly consisted of 5FU and cisplatin that was the preferred regimen in France for anal SCC before the final results of Intergroup RTOG 9811 phase III trial [23]. The combination of 5FU with mitomycin C is currently the standard regimen used with concurrent radiation therapy in anal SCC, providing higher colostomy free and overall survival rates compared to 5FU and cisplatin [23]. In our series, six patients (26\%) had a colostomy, among them four at the time of APR, one for tumor progression with rectal ulceration, and one for grade 4 rectal toxicity. This illustrates clearly the major challenges we have to face: disease control, organ preservation, and radiation induced morbidity.

Intensity-modulated radiation therapy (IMRT) is a highly conformal mode of radiation delivery that allows for relative sparing of nearby normal structures while maintaining or increasing dose to the target volume. For anal SCC, skin and gastrointestinal acute toxicity can require treatment breaks that could impact unfavourably on treatment outcomes [24]. By sparing normal tissues, IMRT could decrease acute toxicity, resulting in fewer treatment breaks and shorter overall treatment time [25]. This approach may lead to improved disease control and tolerance.

We recommend treating patients with rectal SCC as anal SCC, with curative and preservative intent based on exclusive chemoradiation. Radiation therapy volumes should include the 
tumour, the mesorectum, the presacral nodes, and the internal iliac nodes [26]. The external iliac nodes should also be included for T4 tumours involving anterior structures. The inguinal iliac nodes should be discussed for tumours of the lower third of rectum. The recommended prophylactic dose to non-involved lymph nodes is unclear as patients in this series received either 36 Gy (Besançon) or 45 Gy (Paris). Most authors recommend a minimal dose of 54 Gy to the tumour but it should not exceed 60 Gy as shown for anal SCC by Peiffert et al. in the FFCD-PRODIGE 5 trial [27].

Evaluation of residual tumour is a critical issue. Nahas et al. reported the outcome of seven patients with rectal SCC that underwent salvage surgery after chemoradiation (50.4 Gy with concurrent 5FU-mitomycin C) because of clinical partial response [10]. Six of them had a complete pathologic response. This result raises two questions: imaging methods efficiency and optimal timing of surgery, if indicated.

Cummings et al. showed that regression rate of anal SCC over time was not an optimal measure of the treatment effectiveness: median time to complete response was three months, but some tumours could take up to 12 months to disappear [28]. This advocates a "wait and see" strategy for patients with persistent disease without progression in anal SCC, and, by extension, rectal SCC.

Use of PET CT has been assessed in recent publications to monitor treatment response and select candidates that really request salvage surgery [29-31]. Yeh et al. reported in four patients with resolution of hypermetabolic activity after preoperative chemoradiation a complete pathology response [21]. In another small series, two out of three patients with pathologic complete response had also a complete metabolic response; for the patient with persistent signal, PET CT was performed only three weeks after completion of CRT [30]. Therefore, authors recommend a delay over six weeks. 
This study has some important limitations. First, this is a retrospective study but this is inherent to the rarity of the disease. Second, the treatments of patients were heterogeneous with different radiation doses and concurrent chemotherapy regimens. However, this is the largest series of rectal SCC to our knowledge demonstrating a high rate of organ preservation with an excellent survival.

Cumulatively, this study and recent publications advocate conservative approach based on exclusive chemo-radiation as primary modality in localized rectal SCC.

Surgery as main treatment is now outdated but should be considered for patients with incomplete tumour response or local recurrence.

\section{Conflict of Interest Statement}

None declared. 


\section{References}

[1] Raiford TS, Buttles EM. Primary Mucoid Carcinoma of the Rectum in a Thirteen-YearOld Girl. Ann Surg 1933;97:903-9.

[2] Williams GT, Blackshaw AJ, Morson BC. Squamous carcinoma of the colorectum and its genesis. J Pathol 1979;129:139-47.

[3] Lafreniere R, Ketcham AS. Primary squamous carcinoma of the rectum. Report of a case and review of the literature. Dis Colon Rectum 1985;28:967-72.

[4] Schlienger M, Krzisch C, Pene F, et al. Epidermoid carcinoma of the anal canal treatment results and prognostic variables in a series of 242 cases. Int J Radiat Oncol Biol Phys 1989;17:1141-51.

[5] ICRU: Prescribing recording and reporting photon therapy, Report 50,1993 1993.

[6] Matzinger O, Roelofsen F, Mineur L, Koswig S, Van Der Steen-Banasik EM, Van Houtte P, et al., EORTC Radiation Oncology and Gastrointestinal Tract Cancer Groups. Mitomycin $\mathrm{C}$ with continuous fluorouracil or with cisplatin in combination with radiotherapy for locally advanced anal cancer (European Organisation for Research and Treatment of Cancer phase II study 22011-40014). Eur J Cancer 2009;45:2782-91.

[7] Deniaud-Alexandre E, Touboul E, Tiret E, et al. Results of definitive irradiation in a series of 305 epidermoid carcinomas of the anal canal. Int $\mathrm{J}$ Radiat Oncol Biol Phys 2003;56:1259-73.

[8] LENT SOMA scales for all anatomic sites. Int J Radiat Oncol Biol Phys 1995;31:104991.

[9] Mantel N. Evaluation of survival data and two new rank order statistics arising in its consideration. Cancer Chemother Rep 1966;50:163-70.

[10] Nahas CSR, Shia J, Joseph R, et al. Squamous-cell carcinoma of the rectum: a rare but curable tumor. Dis Colon Rectum 2007;50:1393-400.

[11] Sturgeon JD, Crane CH, Krishnan S, et al. Definitive Chemoradiation for Squamous Cell Carcinoma of the Rectum. Am J Clin Oncol 2014 Sep 12 [Epub ahead of print].

[12] Péron J, Bylicki O, Laude C, Martel-Lafay I, Carrie C, Racadot S. Nonoperative management of squamous-cell carcinoma of the rectum. Dis Colon Rectum 2015;58:60-4.

[13] Musio D, De Felice F, Manfrida S, et al. Squamous cell carcinoma of the rectum: The treatment paradigm. Eur J Surg Oncol 2015;41:1054-8.

[14] Clark J, Cleator S, Goldin R, Lowdell C, Darzi A, Ziprin P. Treatment of primary rectal squamous cell carcinoma by primary chemoradiotherapy: should surgery still be considered a standard of care? Eur J Cancer 2008;44:2340-3.

[15] Audeau A, Han HW, Johnston MJ, Whitehead MW, Frizelle FA. Does human papilloma virus have a role in squamous cell carcinoma of the colon and upper rectum? Eur J Surg Oncol 2002;28:657-60.

[16] Tronconi MC, Carnaghi C, Bignardi M, et al. Rectal squamous cell carcinoma treated with chemoradiotherapy: report of six cases. Int J Colorectal Dis 2010;25:1435-9.

[17] Dyson T, Draganov PV. Squamous cell cancer of the rectum. World J Gastroenterol WJG 2009;15:4380-6.

[18] Vezeridis MP, Herrera LO, Lopez GE, Ledesma EJ, Mittleman A. Squamous-cell carcinoma of the colon and rectum. Dis Colon Rectum 1983;26:188-91.

[19] Pigott JP, Williams GB. Primary squamous cell carcinoma of the colorectum: case report and literature review of a rare entity. J Surg Oncol 1987;35:117-9.

[20] Rasheed S, Yap T, Zia A, McDonald PJ, Glynne-Jones R. Chemo-radiotherapy: an alternative to surgery for squamous cell carcinoma of the rectum--report of six patients and literature review. Colorectal Dis 2009;11:191-7. 
[21] Yeh J, Hastings J, Rao A, Abbas MA. Squamous cell carcinoma of the rectum: a single institution experience. Tech Coloproctology 2012;16:349-54. doi:10.1007/s10151-012-0848-z.

[22] Jeong BG, Kim DY, Kim SY. Concurrent chemoradiotherapy for squamous cell carcinoma of the rectum. Hepatogastroenterology 2013;60:512-6. doi:10.5754/hge11293.

[23] Gunderson LL, Winter KA, Ajani JA, et al. Long-term update of US GI intergroup RTOG 98-11 phase III trial for anal carcinoma: survival, relapse, and colostomy failure with concurrent chemoradiation involving fluorouracil/mitomycin versus fluorouracil/cisplatin. J Clin Oncol 2012;30:4344-51.

[24] Ben-Josef E, Moughan J, Ajani JA, et al. Impact of overall treatment time on survival and local control in patients with anal cancer: a pooled data analysis of Radiation Therapy Oncology Group trials 87-04 and 98-11. J Clin Oncol 2010;28:5061-6.

[25] Salama JK, Mell LK, Schomas DA, et al. Concurrent chemotherapy and intensitymodulated radiation therapy for anal canal cancer patients: a multicenter experience. J Clin Oncol 2007;25:4581-6.

[26] NCCN guidelines for anal carcinoma version 4.2013 n.d.

[27] Peiffert D, Tournier-Rangeard L, Gérard J-P, et al. Induction chemotherapy and dose intensification of the radiation boost in locally advanced anal canal carcinoma: final analysis of the randomized UNICANCER ACCORD 03 trial. J Clin Oncol 2012;30:1941-8.

[28] Cummings BJ, Keane TJ, O’Sullivan B, Wong CS, Catton CN. Epidermoid anal cancer: treatment by radiation alone or by radiation and 5-fluorouracil with and without mitomycin $\mathrm{C}$. Int J Radiat Oncol Biol Phys 1991;21:1115-25.

[29] Sanal SM, Sivrikoz ON, Karapolat I, Karademir S. Complete clinical response in squamous cell carcinoma of the rectum with liver metastases. J Clin Oncol 2011;29:e806-8.

[30] Wang MLC, Heriot A, Leong T, Ngan SYK. Chemoradiotherapy in the management of primary squamous-cell carcinoma of the rectum. Colorectal Dis 2011;13:296-301.

[31] Brammer RD, Taniere P, Radley S. Metachronous squamous-cell carcinoma of the colon and treatment of rectal squamous carcinoma with chemoradiotherapy. Colorectal Dis 2009;11:219-20. 
Figure Legends

Figure 1. Cumulative incidence of local failure for all patients.

Figure 2. Kaplan Meier disease free survival curve for all patients.

Figure 3. Kaplan Meier overall survival curve for all patients. 
Table 1. Characteristics of patients.

Table 2. Treatment characteristics and tumor response for all patients.

Table 3. Largest series on chemoradiation for rectal squamous cell carcinoma. 
Table 1. Characteristics of patients.

\begin{tabular}{|c|c|c|}
\hline \multirow[t]{2}{*}{ Parameter } & \multicolumn{2}{|c|}{ Total } \\
\hline & $\mathrm{N}$ & $\%$ \\
\hline \multicolumn{3}{|l|}{ Age (years) } \\
\hline Mean & 59.5 & \\
\hline Median & 59 & \\
\hline Range & $42-88$ & \\
\hline \multicolumn{3}{|l|}{ Sex } \\
\hline Male & 3 & 13 \\
\hline Female & 20 & 87 \\
\hline \multicolumn{3}{|l|}{ Tumor location } \\
\hline Middle rectum & 7 & 30 \\
\hline Low rectum & 16 & 70 \\
\hline \multicolumn{3}{|l|}{ Tumor grade } \\
\hline Well differenciated & 5 & 21 \\
\hline Moderately & 13 & 57 \\
\hline differenciated & 2 & 9 \\
\hline $\begin{array}{l}\text { Poorly differenciated } \\
\text { Unknown }\end{array}$ & 3 & 13 \\
\hline \multicolumn{3}{|l|}{ Tumor length (mm) } \\
\hline Mean & 49 & \\
\hline Median & 52 & \\
\hline Range & $10-100$ & \\
\hline \multicolumn{3}{|l|}{$\begin{array}{l}\text { Distance from anal } \\
\text { sphincter }(\mathbf{m m})\end{array}$} \\
\hline Mean & 31 & \\
\hline Median & 20 & \\
\hline Range & $10-80$ & \\
\hline \multicolumn{3}{|l|}{$\begin{array}{l}\text { Rectal } \\
\text { circumference } \\
\text { involved }\end{array}$} \\
\hline $25 \%$ & 11 & 48 \\
\hline $50 \%$ & 6 & 26 \\
\hline $75 \%$ & 3 & 13 \\
\hline $100 \%$ & 3 & 13 \\
\hline \multicolumn{3}{|l|}{ Stage T } \\
\hline $\mathrm{T} 1$ & 4 & 17 \\
\hline $\mathrm{T} 2$ & 4 & 17 \\
\hline $\mathrm{T} 3$ & 9 & 40 \\
\hline $\mathrm{T} 4$ & 6 & 26 \\
\hline \multicolumn{3}{|l|}{ Stage N } \\
\hline NO & 7 & 30 \\
\hline N1 & 14 & 61 \\
\hline $\mathrm{N} 2$ & 2 & 9 \\
\hline Total & 23 & 100 \\
\hline
\end{tabular}

Abbreviations: $\mathrm{N}$, number of patients; $\mathrm{T}$, tumor; $\mathrm{N}$, node. 
Table 2. Treatment characteristics and tumor response for all patients.

\begin{tabular}{|c|c|c|c|c|c|c|c|c|}
\hline Patients & Center & $\begin{array}{c}\text { First } \\
\text { course } \\
\text { dose }(\mathbf{G y}) \\
\end{array}$ & $\begin{array}{c}\text { Concurrent } \\
\text { chemotherapy }\end{array}$ & $\begin{array}{c}\text { Tumor } \\
\text { response }\end{array}$ & $\begin{array}{l}\text { Boost } \\
\text { dose } \\
(\text { Gy }) \\
\end{array}$ & $\begin{array}{l}\text { Total } \\
\text { dose } \\
(\mathbf{G y}) \\
\end{array}$ & $\begin{array}{c}\text { Treatment } \\
\text { length } \\
\text { (day) }\end{array}$ & $\begin{array}{c}\text { Tumor } \\
\text { response }\end{array}$ \\
\hline 1 & Tenon & 45 & CDDP-5FU & $100 \%$ & 16 & 61 & 77 & $100 \%$ \\
\hline 2 & Tenon & 45 & CDDP-5FU & $>50 \%$ & 16 & 61 & 89 & $100 \%$ \\
\hline 3 & Tenon & 45 & CDDP-5FU & $>50 \%$ & 20 & 65 & 99 & $100 \%$ \\
\hline 4 & Tenon & 47 & CDDP-5FU & $>50 \%$ & 16 & 63 & 94 & $100 \%$ \\
\hline 5 & Tenon & 45 & CDDP-5FU & $>50 \%$ & 16 & 61 & 94 & $100 \%$ \\
\hline 6 & Tenon & 45 & CDDP-5FU & $<50 \%$ & 16 & 61 & 84 & $100 \%$ \\
\hline 7 & Tenon & 45 & CDDP-5FU & $100 \%$ & 0 & 45 & 34 & APR \\
\hline 8 & Tenon & 45 & None & $>50 \%$ & 20 & 65 & 84 & $100 \%$ \\
\hline 9 & Tenon & 45 & CDDP-5FU & $>50 \%$ & 16 & 61 & 82 & $100 \%$ \\
\hline 10 & Tenon & 45 & CDDP-5FU & $100 \%$ & 0 & 45 & 32 & APR \\
\hline 11 & Tenon & 45 & CDDP-5FU & $100 \%$ & 20 & 65 & 84 & $100 \%$ \\
\hline 12 & Tenon & 45 & CDDP-5FU & $100 \%$ & 16 & 61 & 92 & $100 \%$ \\
\hline 13 & Tenon & 45 & CDDP-5FU & $<50 \%$ & 20 & 65 & 96 & $100 \%$ \\
\hline 14 & Besançon & 36 & Cape-MMC & 0 & 23 & 59 & 65 & $100 \%$ \\
\hline 15 & Besançon & 36 & 5FU-MMC & $>50 \%$ & 24 & 60 & 38 & $100 \%$ \\
\hline 16 & Besançon & 36 & Cape-MMC & $<50 \%$ & 23 & 59 & 80 & $100 \%$ \\
\hline 17 & Besançon & 45 & 5FU-MMC & $>50 \%$ & 18 & 63 & 80 & $100 \%$ \\
\hline 18 & Besançon & 50 & Cape-MMC & $>50 \%$ & 16 & 67 & 92 & $100 \%$ \\
\hline 19 & Besançon & 36 & Cape-MMC & $<50 \%$ & 31 & 67 & 70 & 0 \\
\hline 20 & Besançon & 45 & Weekly CDDP & $>50 \%$ & 10 & 55 & 95 & $100 \%$ \\
\hline 21 & Besançon & 36 & 5FU-MMC & 0 & 23 & 59 & 64 & $50 \%$ \\
\hline 22 & Besançon & 36 & CDDP-MMC & $>50 \%$ & 31 & 67 & 64 & $100 \%$ \\
\hline 23 & Besançon & 36 & Weekly CDDP & $>50 \%$ & 23 & 59 & 58 & $100 \%$ \\
\hline
\end{tabular}

Abbreviations: CDDP, cisplatin; 5FU, 5-fluorouracile; Cape, capecitabine; MMC, mitomycin $\mathrm{C}$; APR, abdominoperineal resection. 
Table 3. Largest series on chemoradiation for rectal squamous cell carcinoma.

\begin{tabular}{|c|c|c|c|c|c|c|}
\hline Author & $\mathbf{N}$ & Treatment & $\begin{array}{c}\text { CCR } \\
(\%)\end{array}$ & $\begin{array}{c}\text { Recurrence } \\
(\%)\end{array}$ & $\begin{array}{c}\text { Surgery } \\
(\%)\end{array}$ & $\begin{array}{c}\text { 5-year overall } \\
\text { survival }(\%)\end{array}$ \\
\hline Nahas [10] & 12 & $\begin{array}{l}\text { RT 50.4 Gy } \\
\text { 5FU-mito C/cisplatin }\end{array}$ & - & - & 58 & - \\
\hline Clark [14] & 7 & $\begin{array}{l}\text { RT } 50.4 \text { Gy } \\
\text { 5FU-mito C/cisplatin }\end{array}$ & - & - & 14 & - \\
\hline Rasheed [20] & 6 & $\begin{array}{l}\text { RT } 45-50.4 \text { Gy } \\
\text { 5FU-mito C/cisplatin }\end{array}$ & 67 & 17 & 33 & - \\
\hline Tronconi [16] & 6 & $\begin{array}{l}\text { RT 50.4-59.4 Gy } \\
\text { 5FU-mito C/cisplatin }\end{array}$ & 60 & 20 & 50 & - \\
\hline Yeh [21] & 5 & $\begin{array}{l}\text { RT 30-60 Gy } \\
\text { 5FU-mito C/cisplatin }\end{array}$ & 80 & 20 & 40 & 66 \\
\hline Musio [13] & 8 & $\begin{array}{l}\text { RT } 45-70 \text { Gy } \\
\text { 5FU-mito C/oxaliplatin }\end{array}$ & 75 & 12.5 & 25 & - \\
\hline Péron [12] & 11 & $\begin{array}{l}\text { RT } 45-62 \text { Gy } \\
\text { 5FU-mito C/cisplatin }\end{array}$ & 64 & 18 & 36 & - \\
\hline Sturgeon [11] & 14 & $\begin{array}{l}\text { RT 38-58 Gy } \\
\text { cisplatin-5FU/cape }\end{array}$ & - & 21 & 14 & 81 \\
\hline Present study & 23 & $\begin{array}{l}\text { RT } 45-65 \text { Gy } \\
\text { 5FU-mito C/cisplatin }\end{array}$ & 83 & 22 & 26 & 86 \\
\hline
\end{tabular}

Abbreviations: N, number of patients; CCR, complete clinical response; RT, radiation therapy ; 5-FU, 5-fluorouracil; mito $\mathrm{C}$, mitomycine $\mathrm{C}$; cape, capecitabine. 
Loganadane $\mathrm{G}$ et al.

Figure Legends

Figure 1. Cumulative incidence of local failure for all patients.

Figure 2. Kaplan Meier disease free survival curve for all patients.

Figure 3. Kaplan Meier overall survival curve for all patients. 
Table 1. Characteristics of patients.

Table 2. Treatment characteristics and tumor response for all patients.

Table 3. Largest series on chemoradiation for rectal squamous cell carcinoma. 
Figure 1

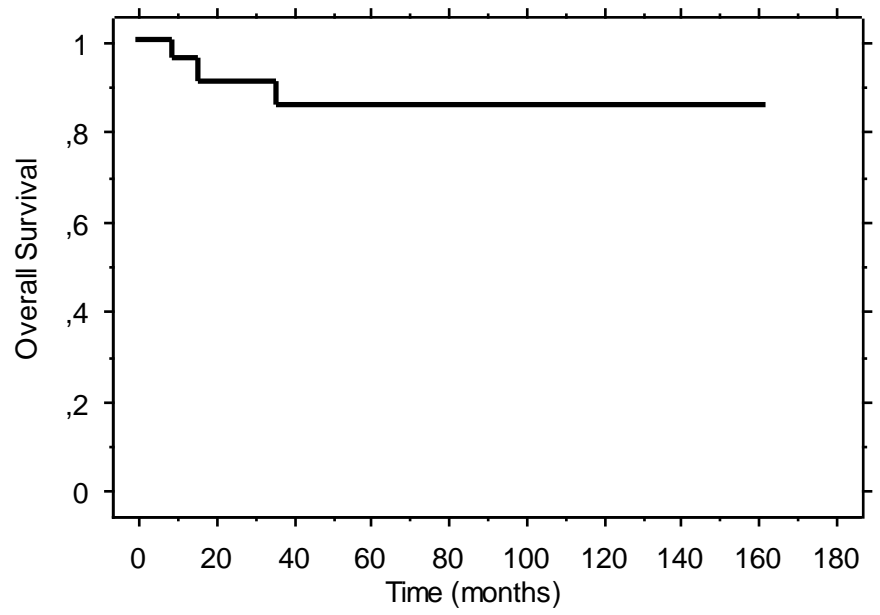


Figure 2

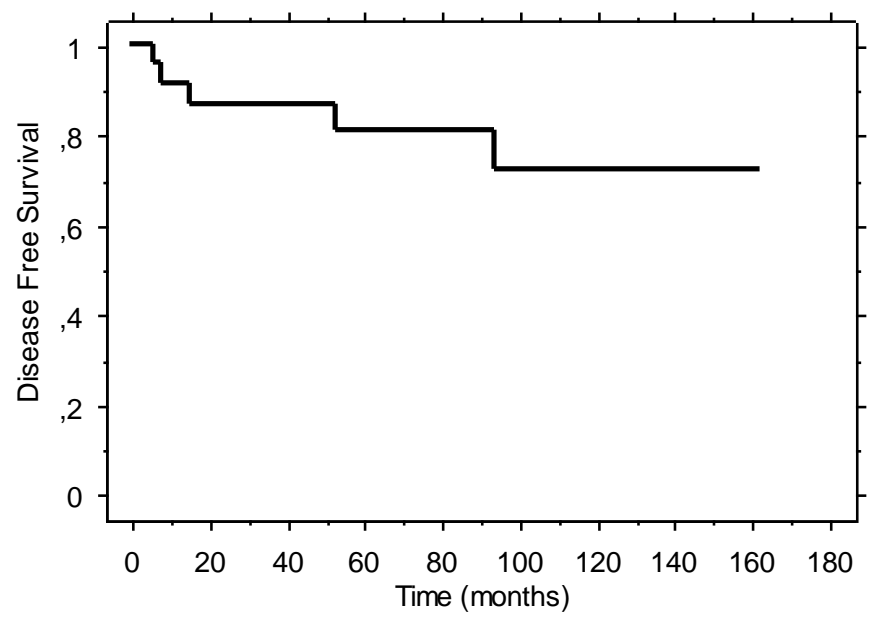


Figure 3

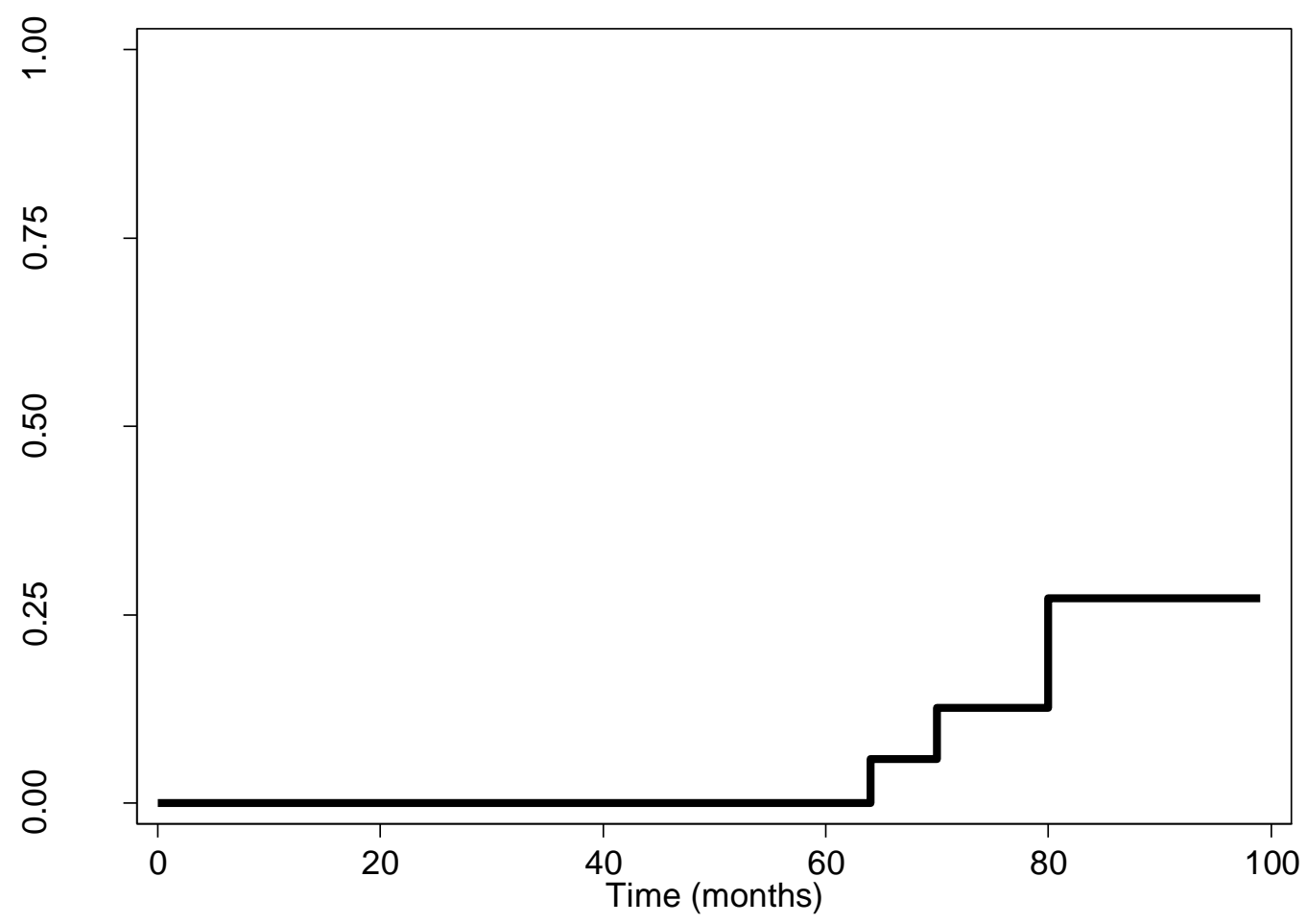

